\title{
AUTONOMOUS WIND POWER SYSTEM FOR REMOTE SHEEP FARMS
}

\author{
Igor Devederkin, Gennady Nikitenko, Sergey Antonov, Alexander Lysakov \\ Stavropol State Agrarian University, Russia \\ devederkin@mail.ru,nikitenko_gv@mail.ru, antonov_serg@mail.ru, s_lysakov@mail.ru
}

\begin{abstract}
Autonomous wind power systems of small capacity are in demand for sheep farms of the North Caucasus Federal district of the Russian Federation. The nature of the production processes of such farms is associated with the parameters and modes of operation of wind power systems. The development of simplified models for calculating the dimensions of wind turbines and the choice of efficient energy converters is an urgent task for the autonomous power supply of the farm. Obtaining eco-friendly meat, or high-quality sheep wool are provided by free-range sheep on pastures with a rich grass area. Sheep flocks are far from power lines. For the power supply of such remote sheep farms, an autonomous wind power system is needed. It must accumulate energy from the wind turbine to perform production processes. Such a farm has a specific daily schedule of electricity consumption, reflecting its use approximately equal to $4.2 \mathrm{~kW}$ per day. The functional scheme and parameters of the autonomous power supply system for sheep farms are presented in this article. The proposed method of calculation connects the aerodynamic parameters of the wind wheel (radius $\mathrm{R}=1.6 \mathrm{~m}$; linear velocity of wind flow $5 \mathrm{~m} \mathrm{~s}^{-1}$ ) with the required electrical power of the generator $0.62 \mathrm{~kW}$. Daily power generation from wind power plants provides charging of batteries with a capacity of 1300 Ah for power supply of the economy for 3 days. The whole system is calculated for a sheepfold with up to 1000 animals. The choice of an effective electromechanical converter for the wind power supply system is justified by the design of a synchronous generator with an original magnetic system. The insertion of ferromagnetic inserts into the magnetic system of the generator increases its output power by $62 \%$. As a confirmation, the article presents graphs of the experimental studies, which reflect the increase in power from the use of original ferromagnetic inserts in the magnetic system of the synchronous generator. Due to the new design features of the synchronous machine, the functional scheme of power supply is simplified and electrical characteristics are improved, which makes this system different from the others.
\end{abstract}

Key words: wind turbine, PMSG, magnetic flux, ferromagnetic elements, sheep breeding.

\section{Introduction}

A special role in the development of walking sheep breeding is played by the grazing region. The natural and climatic zone of the North Caucasus of Russia has good opportunities for sheep breeding. This territory has a juicy fodder base, and an average wind speed of $5 \mathrm{~m} \mathrm{~s}^{-1}$. This allows the use of wind power for seasonal grazing of animals in places without centralized power supply. To date, such scientists as O. Grigorash [1;2], G. Nikitenko [3], S. Voronin [4], R. Amerkhanov [5] are engaged in the research on the development of wind power in this region. The works of these scientists are mainly devoted to the optimization of autonomous power supply systems of remote agricultural facilities with the conversion of wind and solar energy. These studies [6-13] are devoted to improving the efficiency of electromechanical converters for autonomous power supply to the agroindustrial complex objects.

To select the source of autonomous power supply an analysis of the daily electricity consumption of sheep farming was initially carried out. A review of autonomous power supply sources and power generation schemes showed that for decentralized sheep farms with electricity consumption up to 5 $\mathrm{kW}$ per day it is advisable to use an autonomous wind power system with electric storage. In such installation, the generator is connected to a sinusoidal electrical load through a rectifier, charge controller, battery and inverter [1;12]. Currently, the existing charge controllers, batteries and inverters have reached a high degree of technical perfection. Therefore, the development of an autonomous wind power system for a farm should be aimed at a rational relationship between the capacity of the batteries, the geometric dimensions of the wind turbine and the power of the generator. It should also be noted that the effective power supply depends on the design features of the electric generator that generates electricity in the wind turbine. Taking into account the above, it is necessary to calculate the nominal level of electricity generation by the wind turbine and the electric generator for charging the batteries during the periods of idle time of electrical equipment in the standby mode (this means, when energy is not consumed). The accumulated energy in the batteries, during the waiting periods, will provide a stable power supply to sheep farming equipment according to the energy consumption characteristics. 
The electric generators used in small wind turbines are quite metal-intensive, expensive and have large losses of magnetic energy [10;14-16]. In addition, they are complicated by additional sources of excitation to stabilize the rotation speed of the rotor. Based on this, it is recommended to use synchronous generators based on permanent coercive magnets (PMSG) with a high energy reserve in wind turbines of low power. Their designs have the potential efficiency of the magnetic system, but have a high degree of magnetic losses. These losses are not used in magnetoelectric conversion to generate electricity. Therefore, the improvement of PMSG becomes reasonable for autonomous wind farms, if the magnetic losses during the dispersion and buckling of magnetic flows from permanent magnets are concentrated in the windings of the electric generator.

Redistribution of magnetic flux scattering from permanent magnets in the direction of the coil section can be achieved with the help of shielding ferromagnetic inserts and additional poles. Due to the proposed modification of the magnetic system, the design of PMSG can have increased specific and energy characteristics. The proposed technical feature of the PMSG is necessary to use wind power in autonomous power supply systems for objects of low power. The proposed design solutions require theoretical justification and practical confirmation. Therefore, research in this area is relevant. The article is of scientific and practical interest for autonomous power supply using wind energy in farms with consumers of low power up to $5 \mathrm{~kW}$, which include sheep farms.

\section{Materials and methods}

From the daily chart shown in Fig. 1 it can be seen that the peak values of electricity consumed by sheep farming do not exceed $2.3 \mathrm{~kW}$ [18]. Energy is spent on household needs, lighting, pumping and heating water. Peaks in energy consumption continue for 1.5 hours, morning and evening. This corresponds to the production manipulation of animals and the preparation of personnel to work or rest. The amount of time intervals of electricity consumption is 3.5 hours per day. The total amount of electricity consumed during the day is $4.2 \mathrm{~kW}$. Therefore, for short-term peak loads it is not necessary to connect the generator of the corresponding power directly to the inverter, and then to the load. It is necessary to accumulate the generated energy in the batteries during the day and as necessary to spend from the batteries for the needs of the economy.

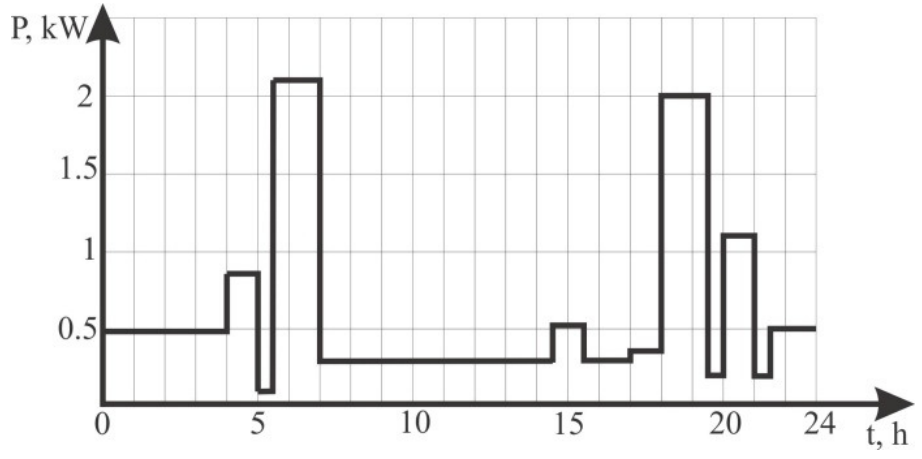

Fig. 1. Daily electricity consumption in sheepfold

For sheep farms that are remote from power lines and consume $5 \mathrm{~kW} / \mathrm{h}$ per day it is advisable to use a wind power system that has batteries as an energy storage device. This system allows to accumulate electricity in the batteries, and through the inverter to convert the energy of the batteries in the appropriate form of a signal that meets the nominal requirements of modern equipment. A simplified functional diagram of this system is shown in Fig. 2.

The wind power plant contains a wind turbine 1 , a power take-off shaft 2 , a synchronous generator 3 on permanent magnets, the installation of which is made in the nacelle and an electric part made of a rectifier 4 , a controller 5 of the battery charge 7 , a ballast load 6 , an inverter 8 , to which the production load 9 is connected.

The power of the system is determined by the parameters of the wind turbine. The calculation is based on the calculation of the area of the bladed surfaces of the blades and the radius of the wind wheel, depending on the wind potential of the region and the power consumption of the load. Such formula (1) is presented in the literature $[7 ; 8 ; 18]$ : 


$$
P=0.5 \pi \rho R^{2} v^{2} C_{p},
$$

where $\rho$-air density, $\rho=1.29 \mathrm{~kg} \cdot \mathrm{m}^{-3}$;

$R$ - radius of the wind wheel;

$v$ - linear velocity of wind flow, $\mathrm{m} \mathrm{s}^{-1}$;

$C_{p}$ - wind utilization rate, $C_{p}=0.38$.

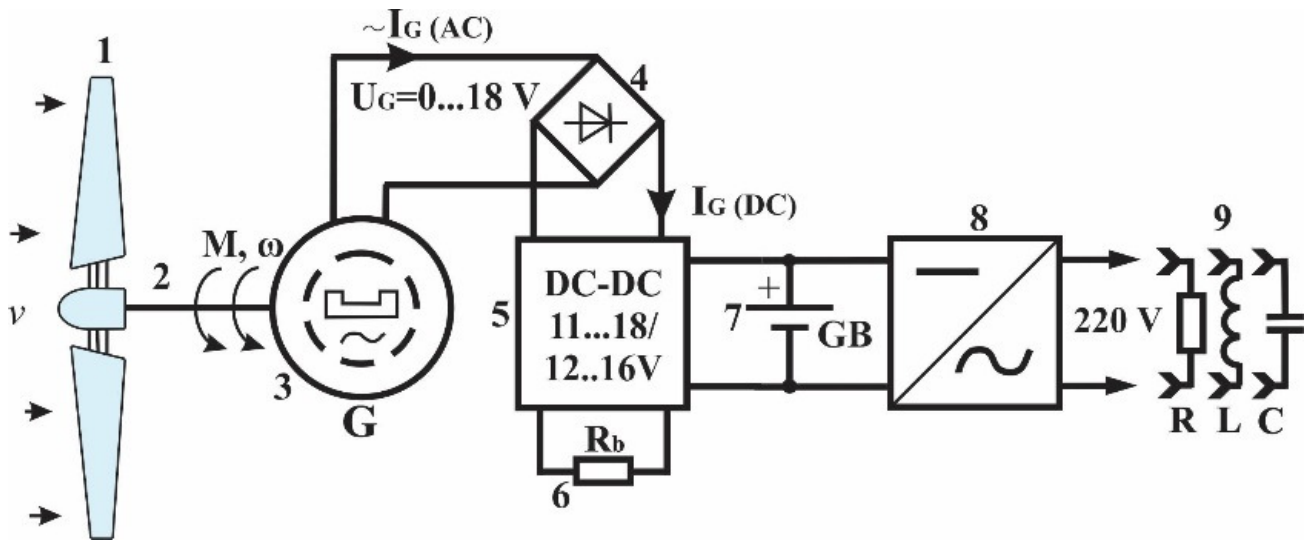

Fig. 2. Functional electrical diagram of autonomous wind power system of sheep farm with synchronous generator

To ensure reliable power supply to the farm at any time of the day, it is necessary to calculate a sufficient amount of generated electricity per hour from PMSG to charge the batteries. The required number of batteries for the autonomous power supply system is calculated from the expression (2):

$$
N_{B}=\frac{P t \alpha_{t}}{U_{B C} C \eta_{B C} \eta_{i n v}},
$$

where $P$-load power $2.5 \mathrm{~kW}$;

$t$ - time of power consumption by load $24, \mathrm{~h}$;

$a_{t}-$ load imbalance factor, $a_{t}=0.083$;

$U_{B C}-$ rated output voltage of the battery capacity $12.8 \mathrm{~V}$;

$C$ - capacity of one battery $200 \mathrm{Ah}$;

$\eta_{B C}-$ utilization of the battery capacity, $\eta_{B C}=0.93$;

$\eta_{i n v}-$ efficiency of the inverter, $\eta_{i n v}=0.98$.

The generated power of PMSG for charging a certain number of batteries is calculated by the following expression (3).

$$
P_{P M S G}=\frac{N_{B} U_{B C} C \eta_{B C} \eta_{\mathrm{inv}}}{t} .
$$

Accordingly, taking into account the three-day windless period, it is necessary to choose six batteries with a total energy consumption of $1200 \mathrm{Ah}$, the charge of which would be provided by an electric generator with a capacity of $600 \mathrm{~W}$.

Knowing the power consumed from the power source and transmitted to the load from the batteries, you can write down the equations expressing the radius of the wind wheel R. To provide the required mechanical power and taking into account the load power, wind speed, wind utilization factor, load time and battery capacity the equation will look like this(4):

$$
R=\sqrt{\frac{N_{B} U_{B C} C \eta_{B C} \eta_{\mathrm{inv}}}{\pi \rho R^{2} v^{3} C_{p} \eta_{\Pi} \eta_{P M S G} \eta_{K}}} .
$$

The results of calculations of the optimal electromechanical parameters of the wind power system for the power supply of sheep farming $(5 \mathrm{~kW})$ are summarized in Table 1. 
The main device for generating electric energy in the wind turbine is the original design of a radial synchronous generator on permanent magnets. The efficiency of this generator is increased by ferromagnetic elements placed in the magnetic system and additional magnetic poles of a special configuration [17].

The program of experiments was carried out to confirm the scientific hypothesis and is aimed at studying the power changes at different design differences of the magnetic system of the synchronous generator. As a result, the magnetoelectric effect of ferromagnetic plates, flat ferromagnetic inserts and triangular magnetic poles, gradually introduced into the magnetic system of a synchronous generator on permanent magnets, is studied. Drawing of a synchronous generator with advanced magnetic system is shown in Fig. 3.

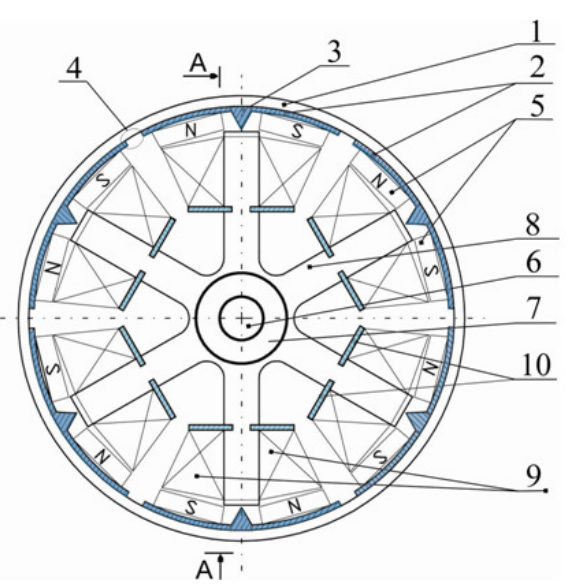

Fig. 3. Synchronous generator: 1 - armature ring; 2 - ferromagnetic plates; 3 - triangular magnetic poles; 4 - air gap; 5 - permanent magnets; 6 - rotation axis; 7 - bearing; 8 - stator poles; 9 - phase windings; 10 - flat ferromagnetic plates

As a result of the physical experiment, the power of the generator was studied depending on the rotation speed in the range from 0 to $1700 \mathrm{rpm}$. The coils of the generator were wound with a winding wire with a diameter of $0.8 \mathrm{~mm}$, which allowed with an increase in the rotational speed of the armature to produce a sinusoidal output voltage.

\section{Results and discussion}

As a result of the mathematical calculation, the optimal electromechanical parameters of the wind energy system for power supply of sheep farms per 1000 heads, with consumed electricity up to $6 \mathrm{~kW}$ per day, are obtained. Table 1 presents the calculation figures.

Table 1

\section{Calculated electromechanical parameters of a wind power system for the sheep farm power supply}

\begin{tabular}{|c|c|c|c|c|}
\hline $\begin{array}{c}\text { Estimated } \\
\text { parameter }\end{array}$ & $\begin{array}{c}\text { Windwheel } \\
\text { radiusR, } \mathbf{m}\end{array}$ & $\begin{array}{c}\text { Wind turbine } \\
\text { power } \boldsymbol{P}, \mathbf{k W}\end{array}$ & $\begin{array}{c}\text { Electricity produced by } \\
\text { the generator to charge } \\
\text { the battery per hour, } \\
\mathbf{k W h}\end{array}$ & $\begin{array}{c}\text { The required } \\
\text { amount of battery } \\
\text { capacity } \mathbf{2 0 0} \mathbf{A h}\end{array}$ \\
\hline Assessed value & 1.60 & 0.68 & 0.62 & 7 \\
\hline
\end{tabular}

As a confirmation of the scientific hypothesis, the results of the experiments are presented. The effect of changing the design of the magnetic system of a permanent-magnet synchronous generator has been experimentally investigated. As it can be seen from the graphs in Fig. 4, there is a positive effect from the ferromagnetic elements and additional magnetic poles in the generator design to increase the generated electrical power.

Analysis of the graphs shows that a synchronous generator without ferromagnetic elements and additional triangular poles develops a power of $100 \mathrm{~W}$ (curve 5, Fig. 4). With the introduction of flat ferromagnetic inserts installed behind the coil into the generator design, the power increases by $9.3 \%$ 
(curve 4, Fig. 4). With the addition of end-to-end ferromagnetic plates with magnets in the magnetic system, the output power rises by $22.5 \%$ (curve 3, Fig. 4). As a result of the installation between the magnets the triangular ferromagnetic poles, the generator power is increased by $30.2 \%$ (curve 2, Fig. 4). Taken together, an experimental sample of a generator with a magnetic system of the ferromagnetic elements listed above and additional magnetic poles increases the power of the synchronous generator by an average of $62 \%$ to achieve a value of $162 \mathrm{~W}$ (curve 1, Fig. 4). The discrepancy with the theoretical calculations is $3 \%$.

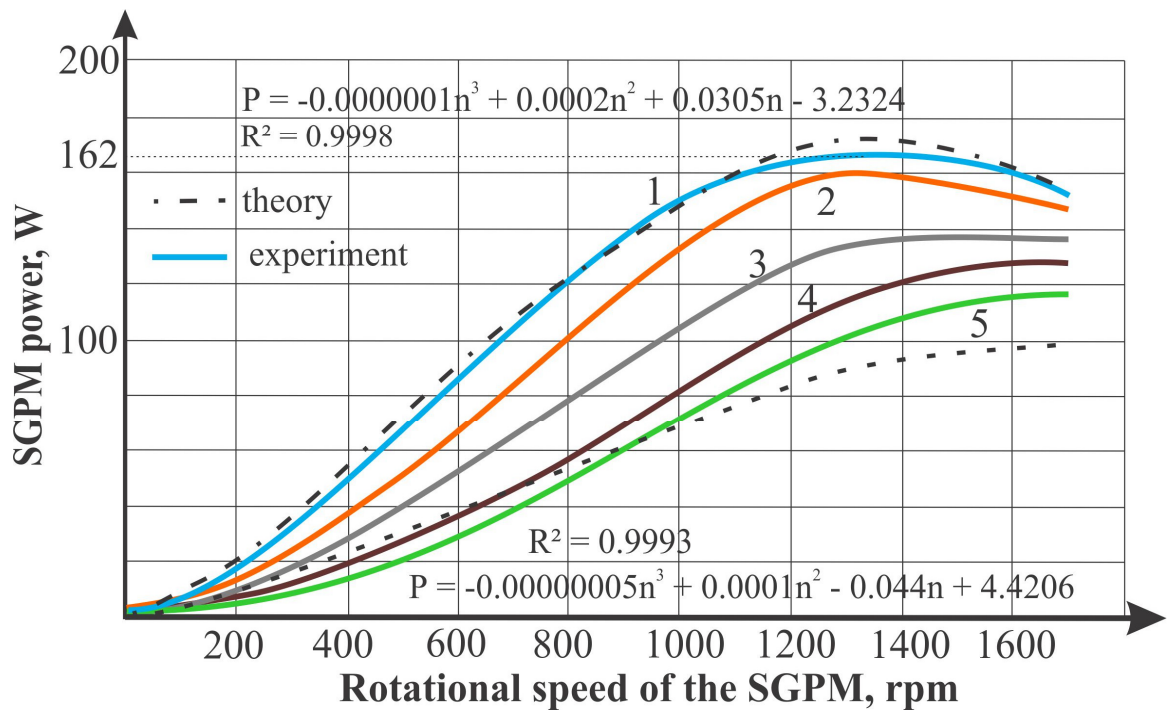

Fig. 4. Dependence of electric power PMSG from rotor speed changing design of magnetic system

\section{Conclusions}

The selected circuit diagram of the autonomous wind energy system for power consumers of small power sheep farms improved the synchronous generator with permanent magnets with ferromagnetic inserts and triangular magnetic poles.

Due to the proposed method of calculating the parameters of the autonomous power supply system of the sheep farm (up to 1000 heads, $4.2 \mathrm{~kW}$ in days), it has been established that with an average wind speed of $5 \mathrm{~m} \mathrm{~s}^{-1}$ the wind turbine should have a blade radius of $1.58 \mathrm{~m}$, the electrical power of the generator $0,62 \mathrm{~kW}$ and the total capacity of the battery $1300 \mathrm{Ah}$.

A prototype of a synchronous generator was made, on the basis of which the experimental studies were conducted on the phased introduction of magnetic elements of the magnetic circuit into its magnetic system. The set of proposed ferromagnetic elements in the design of the PMSG increases the power of the synchronous generator by $62 \%$.

\section{References}

[1] Григораш О.В., Кривошей А.А., Смык В.В. Автономные гибридные электростанции (Autonomous hybrid power plants) Polythematic network electronic journal of the Kuban state agrarian University: Политематический сетевой электронный журнал Кубанского государственного аграрного университета. 2016. №124 (In Russian).

[2] Григораш О.В., Тарасов М.М. О необходимости применения возобновляемых источников энергии (On the need to use renewable sources of energy) Polythematic network electronic journal of the Kuban state agrarian University: Политематический сетевой электронный журнал Кубанского государственного аграрного университета. 2016. №11 (In Russian).

[3] Никитенко Г.В., Коноплёв Е.В. Ветроэнергетические установки в системах автономного электроснабжения: монография (Wind power plants in Autonomous power supply systems: monograph; The Stavropol State Agrarian University - Stavropol) ФГБОУ ВПО Ставроп. гос. аграр. ун-т. - Ставрополь: АГРУС,. 2008. (In Russian). 
[4] Воронин С.М., Закиров И.В., Закиров Ф.В., Определение параметров автономной ветроэлектростанции малой мощности с комбинированным аккумуляторным резервом (Determination of the parameters of an Autonomous low-power wind farm with a combined battery reserve) In book: Fundamental and applied science - 2015 Materials of the XI International scientific and practical conference. 2015. (In Russian).

[5] Амерханов Р.А. Оптимизация сельскохозяйственных энергетических установок с использованием возобновляемых видов энергии (Optimization of agricultural power plants using renewable energy): Kolos, 2003. (In Russian).

[6] Иванова И.Ю., Тугузова Т.Ф., Халгаева Н.А. Определение оптимальной мощности возобновляемого источника энергии для изолированного от энергосистемы потребителя (Determination of the optimal capacity of a renewable energy source for a user isolated from the power system) «Известия Российской академии наук. Энергетика».( "News of the Russian Academy of Sciences. Energy») 2013. №3. (In Russian).

[7] Кривцов В.С., Олейников А.М., Яковлев А.И. Неисчерпаемая энергия, Кн. 1. Ветроэлектрогенераторы: Учебник (Inexhaustible energy, Vol. 1. Wind Turbines: A Tutorial) National aerospace University "Kharkiv aviation Institute. Национальный аэрокосмический университет "Харьковский авиационный институт, 2003. (In Russian).

[8] Лакутин Б.В., Муравлев И.О., Плотников И.А. Децентрализованные системы электроснабжения с ветровыми и солнечными электростанциями: учебное пособие (Decentralized power supply systems with wind and solar power plants: tutorial) publishing House of Tomsk Polytechnic University: Томск: Издательство Томского политехнического университета 2015. (In Russian).

[9] Шерьязов С.К., Шелубаев М.В. Выбор ветроэнергетической установки (The choice of the wind power plant) Mechanization and electrification in agriculture: Механизация и электрификация в сельском хозяйстве. 2010. № 2. (In Russian).

[10]Bogno, B., Sali, M., and Aillerie, M, 2014. Technical and economic analysis of a wind power generation system for rural electrification in Africa // Energy Procedia, 50: 783 p.

[11] Serafim, O.J., J.A. Siqueira, F.F. Putti, L.R. Gabriel Filho and R.S. Daltin, 2014. Energetic exploitation from a hybrid pvwind power micro-generation rural electrification. Energy Procedia, 57: $1475 \mathrm{p}$.

[12] Sigarchian, с. г., А. Малмкуст и т. Франссон, 2014. Моделирование и стратегия управления гибридной системы PV / Wind / Engine / Battery для того чтобы обеспечить электричество и питьевую воду для дистанционных применений. Energy Procedia, 57: 1401 p.

[13] Vadirajacharya, Dr. and P.K. Katti, 2012. Rural Electrification Through Solar and Wind Hybrid System: A Self Sustained Grid Free Electric Power Source. Energy Procedia, 14: 2081 p.

[14]Лифанов, В.А. Расчет электрических машин малой мощности с возбуждением от постоянных магнитов: Учебное пособие (Calculation of low-power electric machines with excitation from permanent magnets: tutorial) Учебное пособие: 2-е изд., перераб. и доп. Челябинск: Издательский центр ЮУрГУ, 2010. (In Russian).

[15]Lui, S., S. Li and L. He, 2012. Direct-driven Permanent Magnet Synchronous Wind-power Generating System with Two Three-level Converters Based on SVPWM Control. Procedia Engineering, 29: $1191 \mathrm{p}$.

[16] You-Young, C., L. Ki-Doek, J. Ik-Sang, K. Mi-Jung and H. Sang-Hwan, 2012. Research on the Output Characteristics of IPMSM according to the Pole-Slot Combinations. Energy Procedia, 14: $1187 \mathrm{p}$.

[17]Никитенко Г.В., Коноплев Е.В., Деведеркин И.В. Высокоэффективный синхронный генератор на постоянных магнитах для ветроэнергетической установки (High efficiency permanent magnet synchronous generator for wind power plant). Vestnik APK Stavropol'ya: Вестник АПК Ставрополья. 2013. №4(12). (In Russian).

[18]Никитенко Г.В., Деведеркин И.В., Коноплев Е.В., Автономная система электроснабжения овцеводческого хозяйства (Autonomous power supply system of sheep-breeding economy). Rural mechanic: Сельский механизатор. 2017. № 1. (In Russian). 